\title{
Immunohistochemical analysis of p53 and p21WAF1/Cip1 expression in primary intracranial germ cell tumors
}

Ryo Nishikawa, M.D., and Masao Matsutani, M.D.

Department of Neurosurgery, Saitama Medical School, Saitama, Japan

Primary intracranial germ cell tumors (GCTs) comprise $3.1 \%$ of all brain tumors and $13.6 \%$ of those in patients younger than 15 years of age in Japan. They are classified into five basic histological types: germinoma, teratoma, choriocarcinoma, yolk sac tumor, and embryonal carcinoma; or into mixed tumor types when they consist of two or more components. Radiation therapy with or without chemotherapy has proven effective in the treatment of germinoma, whereas there is a poor prognosis for choriocarcinoma, yolk sac tumor, embryonal carcinoma, and mixed tumors having components of the group of malignant intracranial GCTs. The underlying mechanisms for such different responses to radio- and chemotherapies of intracranial GCTs remain unknown.

In this study, the authors analyzed the expression of $\mathrm{p} 53$ and $\mathrm{p} 21^{\mathrm{WAF} 1 / \mathrm{Cip} 1}$ proteins by immunohistochemical analysis in 35 intracranial GCTs. Expression of p53 protein was observed in 33 (94\%) of 35 intracranial GCTs. Expression of p21WAF1/Cip1 was detected in seven (20\%) of 35 intracranial GCTs. None of the 15 germinomas was immunoreactive for $\mathrm{p} 21^{\mathrm{WAF} 1 / \mathrm{Cip} 1}$ protein, whereas in a group of malignant intracranial GCTs, four (80\%) of five cases showed immunoreactivity for $\mathrm{p} 21^{\mathrm{WAF} 1 / \mathrm{Cip} 1}$ protein. Analysis of the data suggests that overexpression of $\mathrm{p} 21 \mathrm{WAF} 1 / \mathrm{Cip} 1$ in intracranial GCTs may correlate with decreased sensitivity to radio- and chemotherapy and suggest a poor prognosis.

\section{Key Words * germ cell tumor * p53* p21WAF1/Cip1 * immunohistochemistry}

The primary intracranial germ cell tumors (GCTs) are classified into the five basic histological types of germinoma, teratoma, choriocarcinoma, yolk sac tumor, and embryonal carcinoma, or they are classified into mixed tumor types when they consist of two or more components.[18] In Western countries, GCTs constitute only 0.3 to $0.5 \%$ of all primary brain tumors and approximately $3 \%$ of those in children and adolescents,[33] whereas in Japan GCTs account for 3.1\% of all primary brain tumors and $13.6 \%$ of those in children less than 15 years of age.[16] Surgical extirpation followed by radiation therapy with or without chemotherapy has been proven effective in the treatment of germinoma, which has a 5-year survival rate of 95.4\%.[24] On the other hand, choriocarcinoma, yolk sac tumor, embryonal carcinoma, and mixed tumors composed mainly of these tumor types would be categorized into a malignant group of GCTs having a 5-year survival rate of only 17.4\%.[24] Despite intensive treatments including whole-brain radiation with combination chemotherapy, in more than $80 \%$ of the patients with the malignant group of GCTs the tumors recurred and about half of the recurrences were distant metastases. Each type of GCT represents the neoplastic correlate of a cell type from a specific stage of embryonic development: choriocarcinoma corresponds to the trophoblast, yolk sac tumor 
to yolk sac endoderm, embryonal carcinoma to the pluripotent stem cell of the embryo proper, teratoma to the embryonic differentiated cell, and germinoma corresponds to the primordial germ cell.[35] Tumor cells resembling the cells from an earlier stage of histogenesis (choriocarcinoma, yolk sac tumor, and embryonal carcinoma) are more malignant and refractory to treatments compared to the more differentiated cells such as teratoma and germinoma cells.[24]

The $\mathbf{p 5 3}$ tumor-suppressor gene is involved in the apoptotic response to radiation therapy and to many chemotherapeutic drugs.[22] Gonadal GCT cells overexpress wild-type p53 protein,[9,13,29,32,36] and GCT cells undergo p53-mediated apoptosis in response to DNA damage.[23] The p21WAF1/Cip1 is a downstream effector in the p53 pathway of growth control in mammalian cells.[5] In response to DNA damage, p53 expression promotes the transcription of $\mathrm{p} 21 \mathrm{WAF} 1 / \mathrm{Cip} 1$ resulting in growth arrest through inhibition of cyclin-dependent kinases, which are required for $\mathrm{G} 1$ to $\mathrm{S}$ transition.[14,26,44] When overexpressed in tumor cells, p21 WAF1/Cip1 inhibits cell growth.[5,45] On the other hand, p21WAF1/Cip1 can also be induced by p53-independent pathways $[25,28,39]$ and protects normal cells as well as cancer cells from apoptosis.[11,12,19,30,31,34,42,43] Cells that are resistant to apoptosis will be less responsive to treatment. In some cancers, including acute myelogenous leukemia, head-and-neck cancer, and breast cancer, elevated levels of $\mathrm{p} 21^{\mathrm{WAF} 1 / \mathrm{Cip} 1}$ expression were shown to be associated with increased resistance to chemotherapy and shorter relapse-free survival rates.[1,7,46]

In this study, we investigated the expression of $\mathrm{p} 53$ and $\mathrm{p} 21^{\mathrm{WAF} 1 / \mathrm{Cip} 1}$ proteins by immunohistochemical analysis in 35 primary intracranial GCTs. Our aim was to compare the expression of those two proteins to the clinicopathological characteristics of the tumors including histological classification and treatment response.

\section{CLINICAL MATERIAL AND METHODS}

Thirty-five primary intracranial GCTs from 34 patients were obtained at surgery. Both primary and recurrent tumors were available from one patient with an immature teratoma. Eleven cases of germinoma, four cases of germinoma with syncytiotrophoblastic giant cells (STGCs), nine cases of immature teratoma, two mature teratomas, four mixed tumors of germinoma and immature teratoma components, two choriocarcinomas, one yolk sac tumor, one embryonal carcinoma, and one mixed tumor of embryonal carcinoma and germinoma components were included. All the histological sections were reevaluated by one of the authors (M.M.), and the classification was confirmed by immunohistochemical staining for tumor markers including human chorionic gonadotropin-beta, alpha-fetoprotein, and placental alkaline phosphatase when necessary. All patients underwent radiotherapy after surgery except for one with a mature teratoma that was completely resected. Except for the cases treated before 1981, all patients received adjuvant chemotherapy including cisplatin or carboplatin before or after radiation therapy.

\section{Immunohistochemical Analysis}

Surgically resected tissues were fixed in $10 \%$ formalin and embedded in paraffin. Sections ( $4 \mu \mathrm{m}$ thick) were deparaffinized, rehydrated, and incubated in hydrogen peroxide to block endogenous peroxidase activity in a standard manner. An anti-p53 monoclonal antibody, DO-7 (DAKO A/S, Copenhagen, Denmark), was diluted (1:50) and applied to sections with a microwave treatment for antigen retrieval. The sections were incubated for 1 hour at room temperature. An anti-p21 WAF1/Cip1 monoclonal antibody, EA10 (Oncogene Research Products, Cambridge, MA), was diluted (1:10) and applied to sections with a heat treatment using a pressure cooker, and they were incubated for 18 hours at 4 šC. A standard avidin-biotin complex (ABC) method was used according to the manufacturer's recommendations (Vectastain, Vector Laboratory, Inc., Burlingame, CA) and diaminobenzidine tetrahydrochloride was used to visualize the immunoreactivities. Slides were lightly counterstained with hematoxylin. For negative control, phosphate-buffered saline was used in place of 
primary antibodies. Staining for p21WAF1/Cip1 was nuclear and intense in vascular smooth-muscle cells when present, which served as positive internal controls. Immunoreactivities were scored as absent, focal, or diffuse for both $\mathrm{p} 53$ and $\mathrm{p} 21^{\mathrm{WAF} 1 / \mathrm{Cip} 1}$ staining.

\section{RESULTS}

\section{Analyses of Germinoma}

Fifteen cases of germinoma, including eleven pure and four germinomas with STGCs, were analyzed. Diffuse nuclear staining for p53 protein was observed in each of the 15 germinomas analyzed. Positive staining was confined to tumor cells and was not present in infiltrating lymphocytes. Although the distribution of p53 immunoreactive cells was diffuse, some tumor cells showed prominent immunoreactivity (Fig. 1). There was no difference in immunoreactivity between pure germinomas and those with STGCs. All 15 cases of germinoma were negative for $\mathrm{p} 21^{\mathrm{WAF} 1 / \mathrm{Cip} 1}$ protein expression.

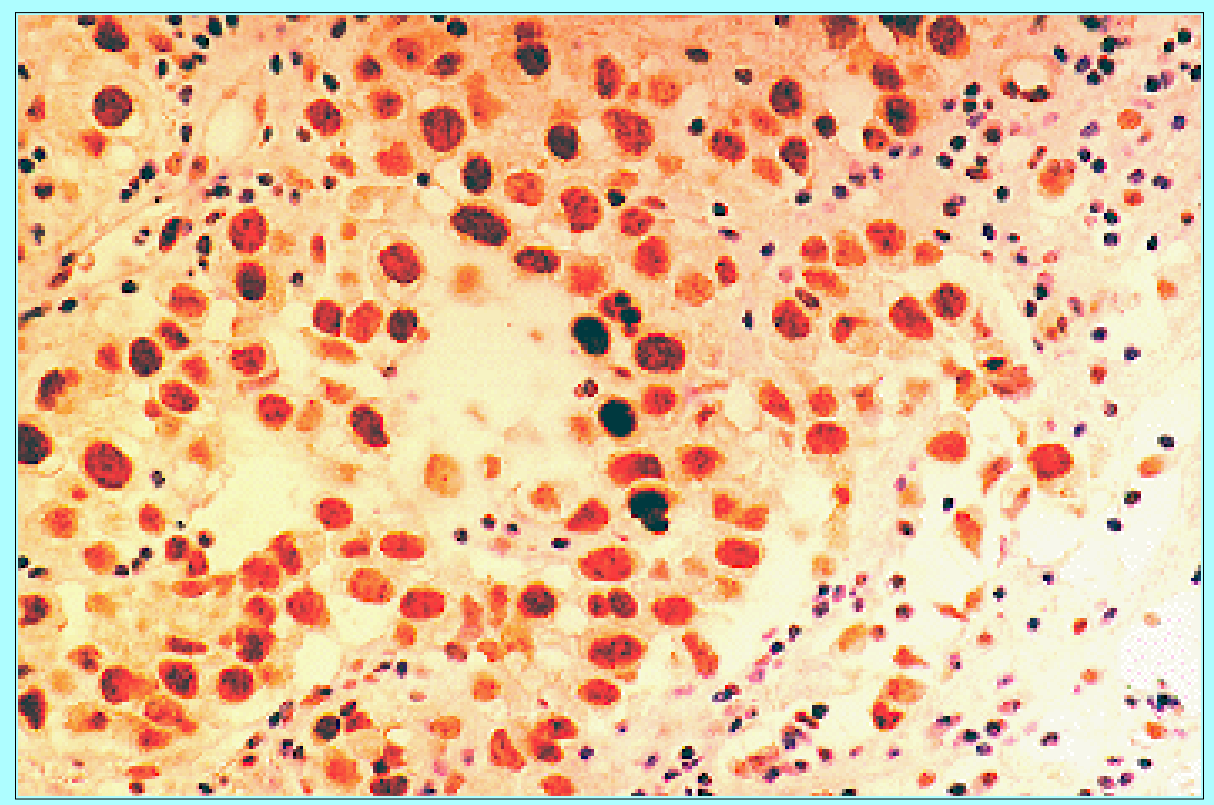

Fig. 1. Case 8. Photomicrograph showing expression of $\mathrm{p} 53$ protein in a germinoma. ABC, original magnification X 400 .

\section{Analyses of Immature and Mature Teratoma}

We analyzed 11 cases of teratoma: nine immature and two mature. Positive immunoreactivity for p53 protein was observed in nine of the 11 tumors: seven of nine immature teratomas and both of the mature teratomas. Immunoreactivity for p53 was localized to tumor cells displaying differentiation into epithelia, whereas other tumor cells were negative for p53 expression (Fig. 2). 


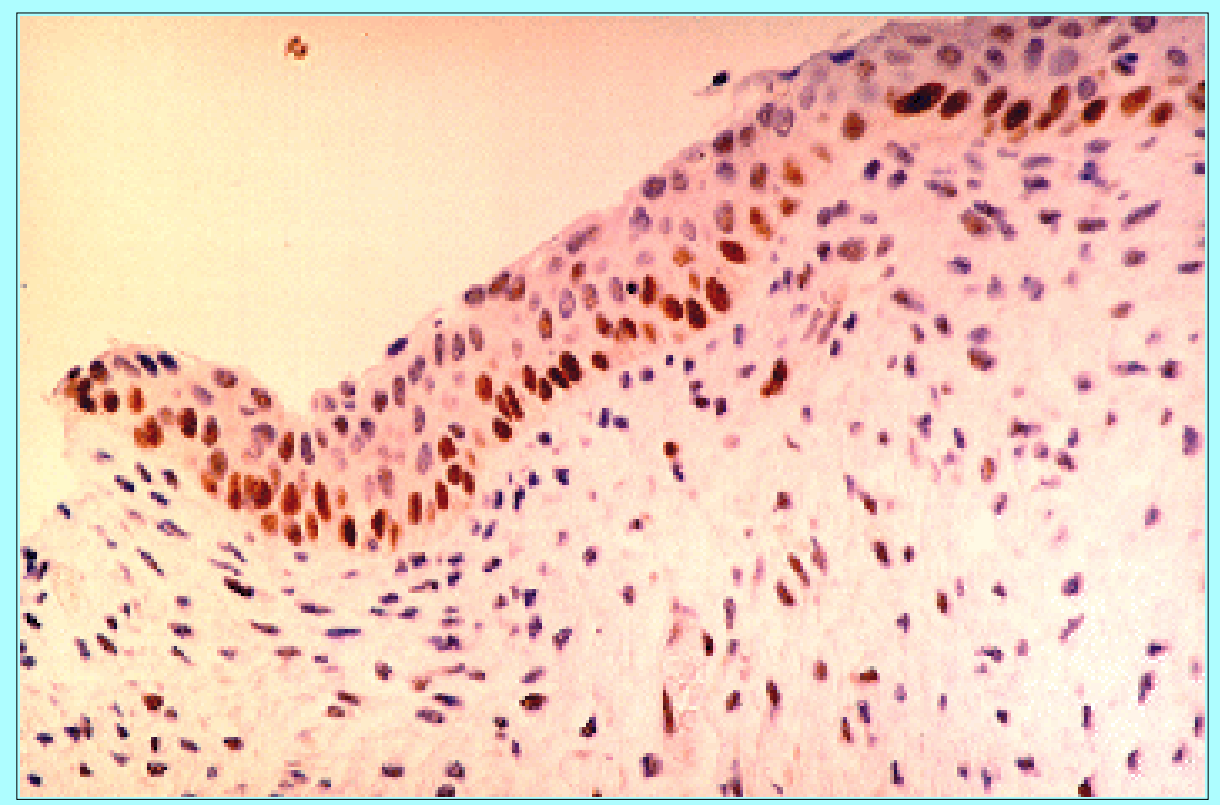

Fig. 2. Case 20. Photomicrograph showing expression of p53 protein confined to tumor cells displaying epithelial differentiation in an immature teratoma. $\mathrm{ABC}$, original magnification $\mathrm{X}$ 400 .

Among the nine teratomas immunoreactive for $\mathrm{p} 53$ protein, three of the tumors (two immature and one mature) showed positive immunoreactivity for $\mathrm{p} 21^{\mathrm{WAF} 1 / \mathrm{Cip} 1}$. Both of the $\mathrm{p} 53$-negative teratomas were also

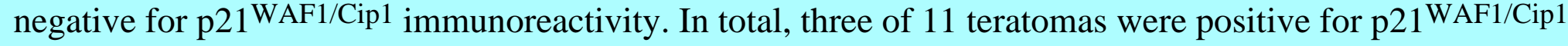
expression. Immunoreactivity for $\mathrm{p} 21^{\mathrm{WAF} 1 / \mathrm{Cip} 1}$ protein was strong in cells displaying epithelial differentiation, similar to that for the p53 protein, although some tumor cells in the mesenchymal component were also positive for $\mathrm{p} 21^{\mathrm{WAF} 1 / \mathrm{Cip} 1}$ expression (Fig. 3). A primary and recurrent tumor from a patient with an immature teratoma were included in this series of samples. Six months after surgery for the primary tumor followed by chemotherapy, the tumor recurred. The histological phenotypes were indistinguishable between the primary and recurrent tumors. Although both tumors were immunoreactive for p53 protein, immunoreactive cells for $\mathrm{p} 21^{\mathrm{WAF} 1 / \mathrm{Cip} 1}$ were observed in the recurrent tumor but not in the primary tumor.

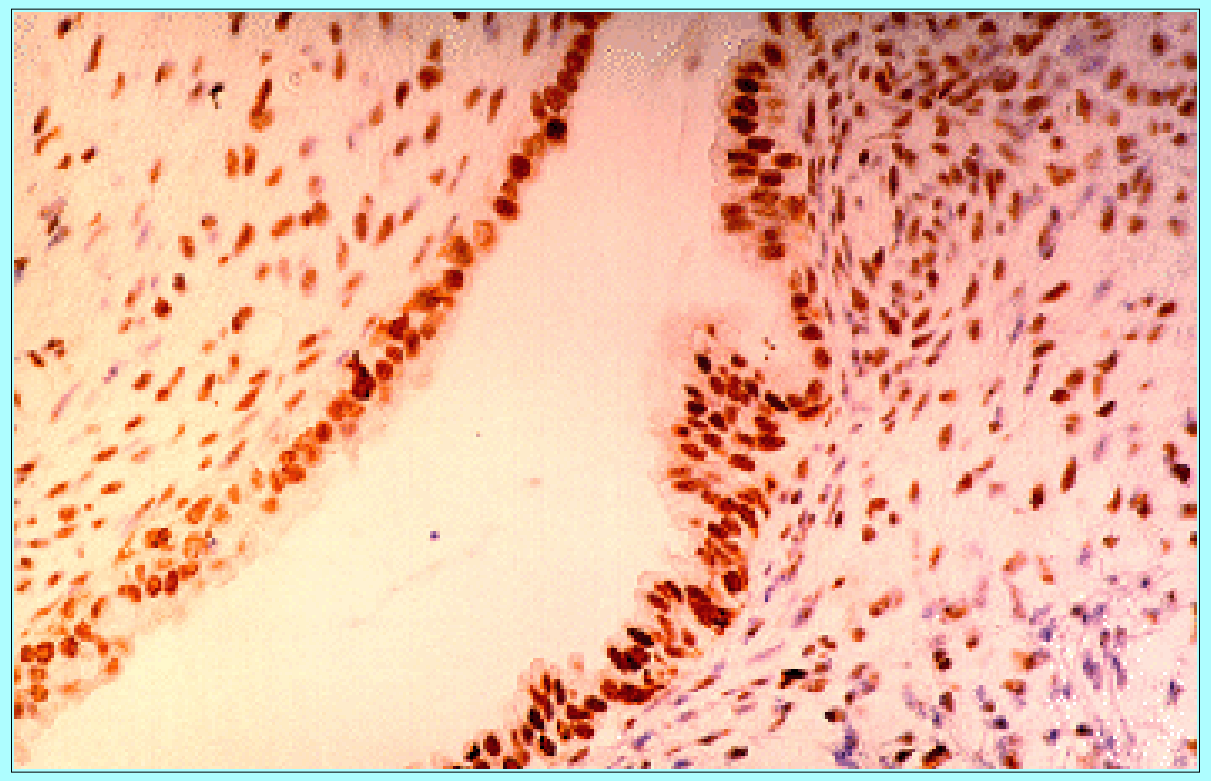

Fig. 3. Case 20. Photomicrograph showing expression of $\mathrm{p} 21^{\mathrm{WAF} 1 / \mathrm{Cip} 1}$ protein in an immature teratoma (a recurrent tumor of Case 20). Immunoreactivity for $\mathrm{p} 21 \mathrm{WAF} 1 / \mathrm{Cip} 1$ protein was strong in cells displaying epithelial differentiation, similar to that for p53, although some tumor cells in 
the mesenchymal component were also positive for $\mathrm{p} 21^{\mathrm{WAF} 1 / \mathrm{Cip} 1}$ expression. $\mathrm{ABC}$, original magnification X 400 .

\section{Analyses of Mixed Tumor of Germinoma and Teratoma Components}

Four tumors of mixed histology consisting of germinoma and teratoma components were analyzed. In each of the four cases, tumor cells in the germinomatous component were immunoreactive for $\mathrm{p} 53$, and the distribution and intensity of staining were similar to those in pure germinomas. In teratomatous components, two of the four mixed tumors showed immunoreactivity for p53 protein localized to tumor cells that displayed epithelial differentiation, similar to that seen in the pure teratomas. Immunoreactivity for $\mathrm{p} 21^{\mathrm{WAF} 1 / \mathrm{Cip} 1}$ protein was not detected in any components of the four mixed tumors analyzed.

\section{Group of Malignant GCTs}

Five cases of GCTs of the malignant group were investigated. Two choriocarcinomas, one yolk sac tumor, one recurrent tumor of embryonal carcinoma treated with radio- and chemotherapy, and one mixed tumor of embryonal carcinoma and germinoma components were included. All five of the malignant GCTs showed immunoreactivity for the $\mathrm{p} 53$ protein, and $\mathrm{p} 21^{\mathrm{WAF} 1 / \mathrm{Cip} 1}$ protein expression was positive in four of the five tumors. Both of the choriocarcinomas showed localized but strong immunoreactivity for both p53 and p21 WAF1/Cip1 proteins as shown in Figs. 4 upper and lower, respectively. The yolk sac tumor showed diffuse immunoreactivity for the $\mathrm{p} 53$ protein and localized immunoreactivity for $\mathrm{p} 21^{\mathrm{WAF} 1 / \mathrm{Cip} 1}$ protein. The embryonal carcinoma component of the mixed tumor showed localized immunoreactivity for both p53 and $\mathrm{p} 21^{\mathrm{WAF} 1 / \mathrm{Cip} 1}$ proteins, whereas the germinomatous component was positive for $\mathrm{p} 53$ and negative for $\mathrm{p} 21^{\mathrm{WAF} 1 / \mathrm{Cip} 1}$ expression, similar to the pure germinomas. A recurrent embryonal carcinoma displayed localized immunoreactivity for $\mathrm{p} 53$ but not for $\mathrm{p} 21^{\mathrm{WAF} 1 / \mathrm{Cip} 1}$ protein. 


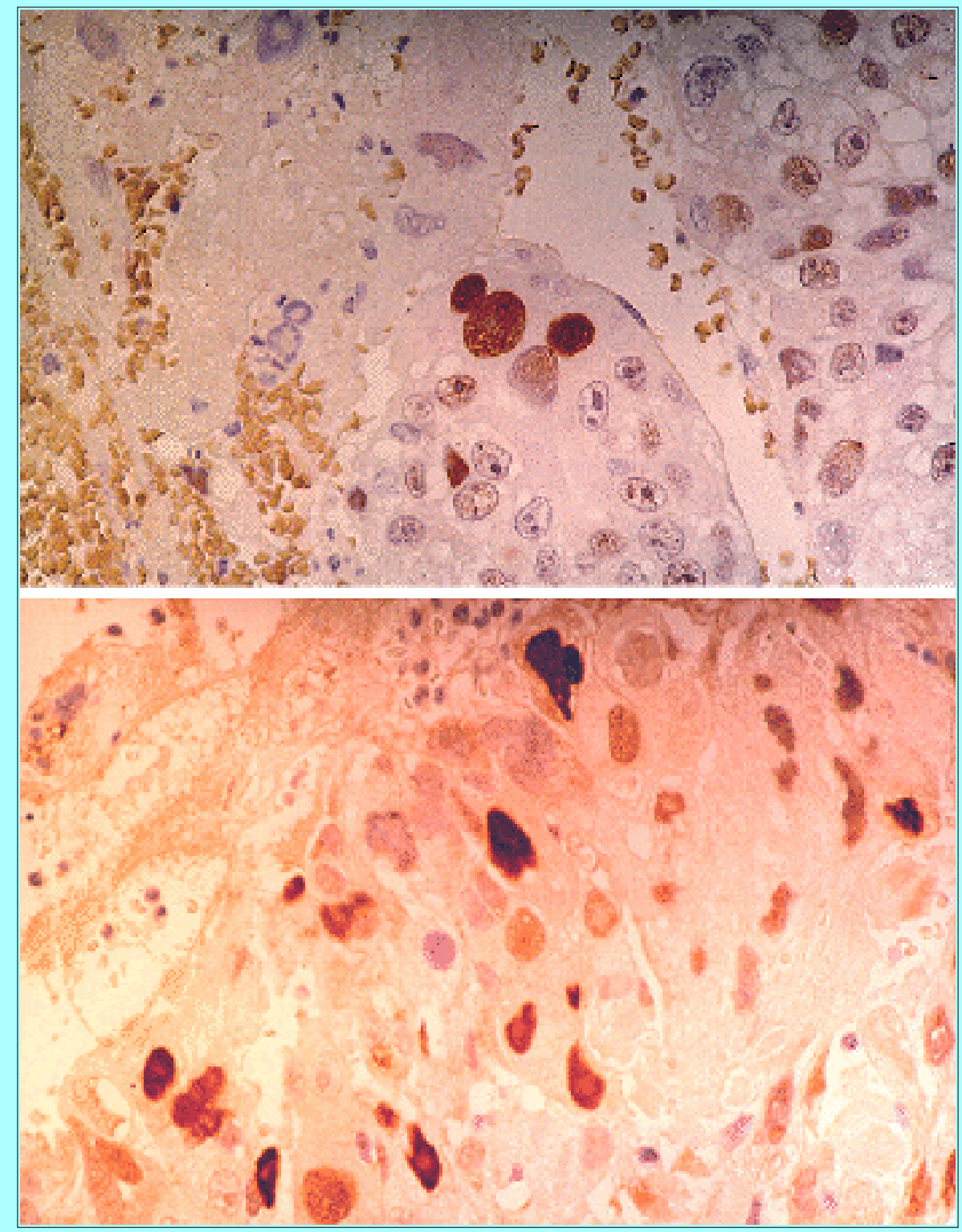

Fig. 4. Case 31. Upper: Photomicrograph showing expression of p53 in a choriocarcinoma. $\mathrm{ABC}$, original magnification $\mathrm{X}$ 400. Lower: Photomicrograph showing expression of $\mathrm{p} 21^{\mathrm{WAF} 1 / \mathrm{Cip} 1}$ in a choriocarcioma. ABC, original magnification X 400.

\section{Correlation Between Expression of p53 and p21 WAF1/Cip1 Proteins and Treatment Results}

Results of immunoreactivity for $\mathrm{p} 53$ and $\mathrm{p} 21^{\mathrm{WAF} 1 / \mathrm{Cip} 1}$ proteins and clinical treatment results of all 34 patients (35 tumors) are summarized in Table 1. 
EXPRESSIN OF P53 AND P21 WAF1/CIP1 PROTEINS AND CL NICAL RESPONSE TO TREATMENT IN 34 PATIENTS WITH INTRACRANIAL GCTS*

\begin{tabular}{|c|c|c|c|c|c|c|}
\hline \multirow{2}{*}{$\begin{array}{l}\text { Case } \\
\text { No. }\end{array}$} & \multirow{2}{*}{$\begin{array}{c}\text { Age (ys) } \\
\text { Sex }\end{array}$} & \multirow{2}{*}{$\begin{array}{l}\text { Tumor } \\
\text { Histology }\end{array}$} & \multirow{2}{*}{$\begin{array}{l}\text { Tumor } \\
\text { Location }\end{array}$} & \multicolumn{2}{|c|}{$\begin{array}{l}\text { Immuno- } \\
\text { hist } \alpha \text { entistry }\end{array}$} & \multirow[b]{2}{*}{ Outcomet } \\
\hline & & & & $p 53$ & $\mathrm{p} 21$ & \\
\hline 1 & $13, M$ & germinoma & pineal & ++ & - & CR for 18 yrs $\ddagger$ \\
\hline 2 & $12, \mathrm{M}$ & germinoma & pineal & ++ & - & CR for 13 yrsf \\
\hline$\overline{3}$ & $27, M$ & germinoma & pineal & ++ & - & CR for 9 yrs \\
\hline 4 & $14 \mathrm{M}$ & germinoma & pineal & ++ & - & CR for 7 yst \\
\hline 5 & $16, M$ & germinoma & pineal & ++ & - & $\mathrm{CR}$ for 6 yrs \\
\hline 6 & $12, M$ & germinoma & pineal & ++ & - & CR for 6 yrs \\
\hline 7 & $19, M$ & germinoma & pineal & ++ & - & CR for 4 yrs \\
\hline 8 & $17 \mathrm{M}$ & germinoma & pineal & ++ & - & CR for 9 irs \\
\hline 9 & $12, M$ & germinoma & pineal & ++ & - & $\mathrm{CR}$ for 3 yrst \\
\hline 10 & $9, F$ & germinoma & neurohypophyseal & ++ & - & CR for 3 yrs \\
\hline 11 & 23 , M & germinoma & pineal \& neurohypophyseal & ++ & - & NA \\
\hline 12 & G. M & germinoma $w / S T G O s$ & neurohypophyseal & ++ & - & CR for 2 ys \\
\hline 13 & $10, M$ & germinoma w/ STGOS & basal ganglia. & ++ & - & $\mathrm{CR}$ for 2 yrs \\
\hline 14 & $14, M$ & germinoma $w / S T G C s$ & pineal & ++ & - & dissem 2 yrs posttreatment \\
\hline 15 & $24, M$ & germinoma w/STGCs & neurohypophyseal & ++ & - & reaur 16 mos posttreatment \\
\hline 16 & $16, M$ & im mature teratoma & pineal & + & - & CR for 7 yrs \\
\hline 17 & $9, M$ & im mature teratoma & in traventricular & - & - & CR for 7 yrs \\
\hline 18 & $8, M$ & im mature teratoma & pineal & + & - & CR for 5 yrs \\
\hline 19 & $14, M$ & im mature teratoma & pineal & + & - & CR for 4 yrs \\
\hline \multirow[t]{2}{*}{20} & $12, \mathrm{M}$ & im mature teratoma & pineal & + & - & recur 6 mos posttreatmentş \\
\hline & & im mature teratoma \| & pineal & + & + & $\mathrm{CR}$ for $3 \mathrm{yrs}$ \\
\hline 21 & $9, F$ & im mature teratoma & neurohypophyseal & - & - & Nম̆ \\
\hline 22 & 24, M & im mature teratoma & neurohypophyseal & + & + & NA \\
\hline 23 & $3 \mathrm{mos}, \mathrm{F}$ & im mature teratoma & cerebellar & + & - & NÁ \\
\hline 24 & $5, M$ & mature teratoma. & pineal & + & + & CR for 17yrst \\
\hline 25 & $3, M$ & mature teratoma & pineal & + & - & CR for $4 y^{x s^{x \pi}}$ \\
\hline 26 & $12, M$ & $\begin{array}{l}\text { germinoma } \\
\text { w/immature teratoma }\end{array}$ & pineal & $\begin{array}{l}++ \\
-\end{array}$ & $\begin{array}{l}- \\
-\end{array}$ & CR for 6 yrs \\
\hline \multirow[t]{2}{*}{27} & $9, M$ & germinoma. & pineal & ++ & - & CR for 5 yrs \\
\hline & & w/immature teratoma & & - & - & \\
\hline \multirow[t]{2}{*}{28} & $20, M$ & germinoma & pineal & ++ & - & CR for 3 yrs \\
\hline & & W/immature teratoma & & + & - & \\
\hline 29 & $18, M$ & $\begin{array}{l}\text { germinoma } \\
\text { w/immature teratoma }\end{array}$ & pineal & $\begin{array}{l}++ \\
+\end{array}$ & $\begin{array}{l}- \\
-\end{array}$ & NÁ \\
\hline \multirow{6}{*}{$\begin{array}{l}30 \\
31 \\
32 \\
33 \\
34\end{array}$} & $11, M$ & choriocarcinom a & pineal & + & + & refractory \& progressive \\
\hline & $20, M$ & choriocarcinoma & neurohypophyseal & + & + & NÁ \\
\hline & $12, \mathrm{M}$ & yolk sac tumor & pineal & ++ & + & dissem 8 mos posttreatment \\
\hline & 24, M & embryonal carcinomatt & pineal & + & - & refractory \& progressive \\
\hline & $23, M$ & em tryonal carcinoma. & pineal & + & + & $\mathrm{CR}$ for 2 yrs \\
\hline & & wigerminoma & & ++ & - & \\
\hline $\begin{array}{c}x \\
\text { recour } \\
\dagger \\
\ddagger \\
\vdots \\
\|_{\pi x} \\
\dagger \dagger\end{array}$ & $\begin{array}{l}\text { CR }=\text { comple } \\
\text { = recurrence } \\
\text { Radio- and o } \\
\text { Treated onl y } \\
\text { Recurrent tud } \\
\text { Recurrent to } \\
\text { No radio- or } \\
\text { Recurrent to }\end{array}$ & $\begin{array}{l}\text { te rem ission; dissem }=\text { diss } \\
\text { of tumor; }-=\text { absent; }+= \\
\text { hemotherapy administered } \\
\text { by surgery and radiation th } \\
\text { hor appeared during sched } \\
\text { or } 6 \text { months after surgery } \\
\text { hemotherapy adm inistered } \\
\text { hor } 9 \text { years after surgery, rs }\end{array}$ & $\begin{array}{l}\text { mination of tum or; } N A=\text { not } \\
\text { cal; }++=\text { diffuse. } \\
\text { ter surgery exoe pt in cases ir } \\
\text { apy. } \\
\text { ed courses of che motherapy } \\
\text { nd chemotherapy. } \\
\text { fter surgery. } \\
\text { io-, and chem otherapy. }\end{array}$ & $\begin{array}{l}\text { oplicat } \\
\text { ticated }\end{array}$ & (follow & up period shorter than 1 year); \\
\hline
\end{tabular}

Among the 14 patients with germinoma with a follow-up period of longer than 1 year, two germinomas with STGCs recurred within 2 years. There were no differences in immunoreactivity for p53 and p21 WAF1/Cip1 proteins in cases with relapse compared with those without relapse, as the expression pattern of both proteins was similar in all the germinomatous cases. 
Eight of the patients with teratomas and three of the patients with mixed tumors of germinoma and teratoma components have been followed for more than 1 year after treatment. Among these 11 tumors, a single immature teratoma recurred in one patient 6 months after the initial surgery and chemotherapy. In the primary tumor, p53-immunoreactivity was present but localized, whereas $\mathrm{p} 21 \mathrm{WAF} 1 / \mathrm{Cip} 1$ immunoreactivity was absent. In the recurrent tumor from this patient, however, expression of $\mathrm{p} 21 \mathrm{WAF} 1 / \mathrm{Cip} 1$ protein was detected. This patient has been tumor-free for more than 3 years since receiving radio- and chemotherapy for the recurrent tumor. All of the other six patients with teratoma and three patients with mixed tumors of germinoma and teratoma components survived more than 3 years without tumor recurrence. Among these nine cases, p53 expression was not detected in one immature teratoma and two teratomatous components of mixed tumor; however, it was present in five teratomas, two teratomatous components of the mixed tumors, and all of the germinomatous components of the mixed tumors. In one case of mature teratoma, $\mathrm{p} 21^{\mathrm{WAF} 1 / \mathrm{Cip} 1}$ staining was positive. Therefore, we could not detect any significant correlation between treatment results and immunoreactivity for $\mathrm{p} 53$ or $\mathrm{p} 21^{\mathrm{WAF} 1 / \mathrm{Cip} 1}$ proteins in the teratomatous cases analyzed.

Among the five GCTs of the malignant group that were analyzed, four cases have been followed for more than 1 year. A patient with a mixed tumor of embryonal carcinoma and germinoma components has been without recurrence for more than 2 years posttreatment, whereas one choriocarcioma and one recurrent embryonal carcinoma were refractory to treatment, and a yolk sac tumor recurred with spinal dissemination 8 months after initial treatment. Immunoreactivity for p53 protein was present in all four of these cases, whereas $\mathrm{p} 21^{\mathrm{WAF} 1 / \mathrm{Cip} 1}$ protein was present in three. The germinomatous component in the mixed tumor of embryonal carcinoma and germinoma was negative for $\mathrm{p} 21 \mathrm{WAF} 1 / \mathrm{Cip} 1$, whereas the embryonal carcinoma component was positive for $\mathrm{p} 21^{\mathrm{WAF} 1 / \mathrm{Cip} 1}$ expression. This patient was the only one in this group to survive more than 2 years. One choriocarcinoma and one yolk sac tumor were immunoreactive for $\mathrm{p} 21$ WAF1/Cip1 protein while a recurrent embryonal carcinoma was negative for $\mathrm{p} 21^{\mathrm{WAF} 1 / \mathrm{Cip} 1}$ expression, and all were refractory to treatment.

\section{DISCUSSION}

In this study, 33 (94\%) of 35 intracranial GCTs were positive for p53 expression, consistent with previous studies on gonadal GCTs.[2,13,21,32,36,40] Although p53 overexpression in tumors is commonly associated with mutation of the $\mathbf{p 5 3}$ gene, $\mathbf{p 5 3}$ mutations have not been found in GCTs overexpressing p53 protein $[9,13,29,32,36]$ except for a few intracranial tumors.[8] On the other hand, expression of $\mathrm{p} 21^{\mathrm{WAF} 1 / \mathrm{Cip} 1}$ protein, a downstream effector of the p53-mediated growth control in mammalian cells, was not detected in testicular GCTs.[13] Overexpression of wild-type p53 in tumor cells generally triggers cell cycle arrest or apoptosis.[20] Absence of $\mathrm{p} 21^{\mathrm{WAF} 1 / \mathrm{Cip} 1}$ expression in gonadal GCTs was suggested as one of the mechanisms by which tumor cells survive the growth-inhibitory pressure induced by accumulated wild-type p53 protein.[13,23] In contrast to the previous study[13] of testicular GCTs, we observed $\mathrm{p} 21^{\mathrm{WAF} 1 / \mathrm{Cip} 1}$ expression in seven $(20 \%)$ of 35 intracranial GCTs: three $(27 \%)$ of 11 teratomas and four (80\%) of five GCTs of the malignant group. Frequent expression of p21 WAF1/Cip1 was observed in various cancers including breast,[1] colon,[41] stomach,[10] pancreas,[4] and glial tumors.[17] In some cancers, including acute myelogenous leukemia, head-and-neck cancer, and breast cancer, elevated levels of $\mathrm{p} 21^{\mathrm{WAF} 1 / \mathrm{Cip} 1}$ expression were associated with increased resistance to chemotherapy as well as with short relapse-free survival.[1,7,46] In cancers of the pancreas, stomach, and uterus, p21 WAF1/Cip1 expression was reported to indicate a better prognosis. $[3,10,15]$ We did not observe a significant correlation between immunoreactivity for $\mathrm{p} 21^{\mathrm{WAF} 1 / \mathrm{Cip} 1}$ protein and treatment results in this study. However, our findings that none of the germinoma cases expressed $\mathrm{p} 21^{\mathrm{WAF} 1 / \mathrm{Cip} 1}$ protein and four of five GCTs of the malignant group expressed $\mathrm{p} 21^{\mathrm{WAF} 1 / \mathrm{Cip} 1}$ protein suggest that expression of $\mathrm{p} 21^{\mathrm{WAF} 1 / \mathrm{Cip} 1}$ in intracranial GCTs may be 
correlated with decreased sensitivity to radio- or chemotherapy and poor prognosis. Clinical analyses for evaluating possible prognostic factors in GCTs may be biased by several factors, including the extent of surgical extirpation, the effect of previous radio- or chemotherapy, and histological heterogeneity of GCTs. For example, an embryonal carcinoma was negative for $\mathrm{p} 21^{\mathrm{WAF} 1 / \mathrm{Cip} 1}$ protein expression but refractory to treatment. However, this tumor had recurred after radio- and chemotherapy, and radiation may have downregulated the expression of $\mathrm{p} 21^{\mathrm{WAF} 1 / \mathrm{Cip} 1}$.[27] On the other hand, a mixed tumor of embryonal carcinoma and germinoma components responded well to therapies, and the tumor has not recurred in the 2 years posttreatment. The section was composed of approximately $50 \%$ embryonal carcinoma and $50 \%$ germinoma, and $\mathrm{p} 21^{\mathrm{WAF} 1 / \mathrm{Cip} 1}$ expression was positive only in the embryonal carcinoma component. The germinomatous component must have responded well to treatment; however, a longer follow-up period is needed. Further studies in a larger patient population are necessary to elucidate whether immunoreactivity for $\mathrm{p} 21^{\mathrm{WAF} 1 / \mathrm{Cip} 1}$ protein could be a prognostic factor in intracranial GCTs.

In teratomas, immunoreactivity for $\mathrm{p} 53$ and $\mathrm{p} 21^{\mathrm{WAF} 1 / \mathrm{Cip} 1}$ proteins was mostly confined to tumor cells displaying epithelial differentiation. Overexpression of $\mathrm{p} 53$ protein in embryonic pulmonary and intestinal epithelia was observed.[37] Upregulation of p53 expression in early stages of mouse embryo development corresponds to each type of malignant GCT: upregulation of p53 expression in chorionic villi in the placenta corresponds to overexpression of $\mathrm{p} 53$ protein in choriocarcinoma; upregulation of p53 expression in yolk sac endoderm corresponds to overexpression of p53 in yolk sac tumor; and upregulation of p53 expression in all tissues of the embryo during early morphogenetic stages corresponds to overexpression of p53 in embryonal carcinoma. As embryonic development enters a phase of organogenesis and histogenesis, the p53 expression pattern becomes heterogeneous and restricted to certain specific tissues, such as lung, intestine, brain, liver, salivary gland, and kidney, which corresponds well to the restricted expression of p53 in teratoma cells displaying epithelial differentiation. Overexpression of $\mathrm{p} 53$ protein in intracranial GCTs can result from a developmental mistiming event, in which genes that are normally expressed in the embryonic period become abnormally upregulated in tumors. In addition, the testis is one of the few adult tissues in which positive staining for p53 has been observed,[38] which again corresponds to the expression of p53 in germinomas.

We found frequent $\mathrm{p} 21 \mathrm{WAF} 1 / \mathrm{Cip} 1$ expression in the most malignant types of GCTs, such as choriocarcinoma, yolk sac tumor, and embryonal carcinoma, and in a few cells displaying epithelial differentiation of teratomas. Upregulation of $\mathrm{p} 21^{\mathrm{WAF} 1 / \mathrm{Cip} 1}$ expression is linked to terminal differentiation of muscle, nasal, pulmonary, and intestinal epithelia, as well as other cell types.[6,28] Contrary to p53 expression, $\mathrm{p} 21^{\mathrm{WAF} 1 / \mathrm{Cip} 1}$ expression was not detected in the early embryonic stage of mouse development, before day 10 postfertilization, except for postmitotic muscle cells.[28] Therefore, $\mathrm{p} 21 \mathrm{WAF} 1 / \mathrm{Cip} 1$ expression in teratoma cells displaying epithelial differentiation may reflect their differentiation status, whereas that in GCTs of the malignant group may be a tumor-specific event.

Several basic issues remain to be solved. First, is the $\mathbf{p 5 3}$ gene wild-type in intracranial GCTs? If the gene is wild-type, similar to that in gonadal GCTs, then how does wild-type p53 protein accumulate and how is $\mathrm{p} 21^{\mathrm{WAF} 1 / \mathrm{Cip} 1}$ expression downregulated in germinomas? Second, what is the biological significance of $\mathrm{p} 21^{\mathrm{WAF} 1 / \mathrm{Cip} 1}$ protein overexpression in the malignant group of intracranial GCTs? Further unraveling of the biological significance of $\mathrm{p} 53$ and $\mathrm{p} 21_{\mathrm{WAF} 1 / \mathrm{Cip} 1}$ expression in intracranial GCTs may lead to more appropriate and successful treatment modalities for tumor types that are now considered to be resistant to treatment.

\section{Acknowledgments}

We thank Mr. Yasuhito Sakai, Ms. Sumiko Ito, and Ms. Naoko Teshima for technical assistance, Dr. Joseph 
F. Costello for critical reading of the manuscript, and the following neurosurgeons and a pathologist for contributing the surgical specimens: Drs. Yasuo Iwasaki, Keiichi Kuwamura, Nobuhiko Takemura, Katsuhisa Ide, Akira Tamura, Soichiro Shibui, Kazuhiro Nomura, Umeo Ito, Hiroshi Segawa, Tsuneyoshi Eguchi, Taku Shigeno, Hirotoshi Otaka, Takao Asao, and Nobuaki Funada.

\section{References}

1. Barbareschi M, Caffo O, Doglioni C, et al: p21 WAF1 immunohistochemical expression in breast carcinoma: correlations with clinicopathological data, oestrogen receptor status, MIB1 expression, p53 gene and protein alterations and relapse-free survival. Br J Cancer 74:208-215, 1996

2. Bartkova J, Bartek J, Lukas J, et al: p53 protein alterations in human testicular cancer including pre-invasive intratubular germ-cell neoplasia. Int J Cancer 49:196-202, 1991

3. Dergham ST, Dugan MC, Joshi US, et al: The clinical significance of p21(WAF1/CIP-1) and p53 expression in pancreatic adenocarcinoma. Cancer 80:372-381, 1997

4. DiGiuseppe JA, Redston MS, Yeo CJ, et al: p53-independent expression of the cyclin-dependent kinase inhibitor p21 in pancreatic carcinoma. Am J Pathol 147:884-888, 1995

5. el-Deiry WS, Tokino T, Velculescu VE, et al: WAF1, a potential mediator of p53 tumor suppression. Cell 75:817-825, 1993

6. el-Deiry WS, Tokino T, Waldman T, et al: Topological control of $\mathrm{p} 21^{\mathrm{WAF} 1 / \mathrm{CIP} 1}$ expression in normal and neoplastic tissues. Cancer Res 55:2910-2919, 1995

7. Erber R, Klein W, Andl T, et al: Aberrant p21(CIP1/WAF1) protein accumulation in head-and-neck cancer. Int J Cancer 74:383-389, 1997

8. Feng X, Zhang S, Ichikawa T, et al: Intracranial germ cell tumors: detection of p53 gene mutations by single-strand conformation polymorphism analysis. Jpn J Cancer Res 86:555-561, 1995

9. Fleischhacker M, Strohmeyer T, Imai Y, et al: Mutations of the p53 gene are not detectable in human testicular tumors. Mod Pathol 7:435-439, 1994

10. Gomyo Y, Ikeda M, Osaki M, et al: Expression of p21 (waf1/cip1/sdi1), but not p53 protein, is a factor in the survival of patients with advanced gastric carcinoma. Cancer 79:2067-2072, 1997

11. Gorospe M, Cirielli C, Wang X, et al: p21 (Waf1/Cip1) protects against p53-mediated apoptosis of human melanoma cells. Oncogene 14:929-935, 1997

12. Gorospe M, Wang X, Guyton KZ, et al: Protective role of p21 (Waf1/Cip1) against prostaglandin A2-mediated apoptosis of human colorectal carcinoma cells. Mol Cell Biol 16:6654-6660, 1996

13. Guillou L, Estreicher A, Chaubert P, et al: Germ cell tumors of the testis overexpress wild-type p53. Am J Pathol 149:1221-1228, 1996

14. Harper JW, Adami GR, Wei N, et al: The p21 Cdk-interacting protein Cip1 is a potent inhibitor of G1 cyclin-dependent kinases. Cell 75:805-816, 1993

15. Ito K, Sasano H, Matsunaga G, et al: Correlations between $\mathrm{p} 21$ expression and clinicopathological findings, p53 gene and protein alterations, and survival in patients with endometrial carcinoma. J Pathol 183:318-324, 1997 
16. The Committee of Brain Tumor Registry of Japan: The seventh report from the brain tumor registry of Japan. Neurol Med Chir 32 (No. 7 Special Issue):381-547, 1992

17. Jung J-M, Bruner JM, Ruan S, et al: Increased levels of p21 Waf1/Cip1 in human brain tumors. Oncogene 11:2021-2028, 1995

18. Kleihues P, Burger PC, Scheithauer BW: Histological Typing of Tumours of the Central Nervous System, ed 2. Berlin: Springer-Verlag, 1993

19. Kobayashi T, Consoli U, Andreeff M, et al: Activation of p21WAF1/Cip1 expression by a temperature sensitive mutant of human p53 does not lead to apoptosis. Oncogene 11:2311-2316, 1995

20. Levine AJ: p53, the cellular gatekeeper for growth and division. Cell 88:323-331, 1997

21. Lewis DJ, Sesterhenn IA, McCarthy WF, et al: Immunohistochemical expression of P53 tumor suppressor gene protein in adult germ cell testis tumors: clinical correlation in stage I disease. J Urol 152:418-423, 1994

22. Lowe SW, Ruley HE, Jacks T, et al: p53-dependent apoptosis modulates the cytotoxicity of anticancer agents. Cell 74:957-967, 1993

23. Lutzker SG, Levine AJ: A functionally inactive p53 protein in teratocarcinoma cells is activated by either DNA damage or cellular differentiation. Nat Med 2:804-810, 1996

24. Matsutani M, Sano K, Takakura K, et al: Primary intracranial germ cell tumors: a clinical analysis of 153 histologically verified cases. J Neurosurg 86:446-455, 1997

25. Michieli P, Chedid M, Lin D, et al: Induction of WAF1/CIP1 by a p53-independent pathway. Cancer Res 54:3391-3395, 1994

26. Noda A, Ning Y, Venable SF, et al: Cloning of senescent cell-derived inhibitors of DNA synthesis using an expression screen. Exp Cell Res 211:90-98, 1994

27. Palazzo JP, Kafka NJ, Grasso L, et al: The role of p53, p21 WAF1/CIP1, and bcl-2 in radioresistant colorectal carcinoma. Hum Pathol 28:1189-1195, 1997

28. Parker SB, Eichele G, Zhang P, et al: p53-independent expression of p21 Cip1 in muscle and other terminally differentiating cells. Science 267:1024-1027, 1995

29. Peng HQ, Hogg D, Malkin D, et al: Mutations of the p53 gene do not occur in testis cancer. Cancer Res 53:3574-3578, 1993

30. Poluha W, Poluha DK, Chang B, et al: The cyclin-dependent kinase inhibitor p21(WAF1) is required for survival of differentiating neuroblastoma cells. Mol Cell Biol 16:1335-1341, 1996

31. Polyak K, Waldman T, He TC, et al: Genetic determinants of p53-induced apoptosis and growth arrest. Genes Dev 10:1945-1952, 1996

32. Riou G, Barrois M, Prost S, et al: The p53 and mdm-2 genes in human testicular germ-cell tumors. Mol Carcinogen 12:124-131, 1995

33. Rosenblum MK, Ng HK: Germ cell tumours, in Kleihues P, Cavenee WK (eds): Pathology and Genetics of Tumours of the Nervous System. Lyon: International Agency for Research on Cancer, 1997, 
pp 164-169

34. Ruan S, Okcu MF, Ren JP, et al: Overexpressed WAF1/Cip1 renders glioblastoma cells resistant to chemotherapy agents 1,3-Bis(2-chloroethyl)-1-nitrosourea and cisplatin. Cancer Res 58:1538-1543, 1998

35. Sano K, Matsutani M, Seto T: So-called intracranial germ cell tumours: personal experience and a theory of their pathogenesis. Neurol Res 8:118-126, 1989

36. Schenkman NS, Sesterhenn IA, Washington L, et al: Increased p53 protein does not correlate to p53 gene mutations in microdissected human testicular germ cell tumors. J Urol 154:617-621, 1995

37. Schmid P, Lorenz A, Hameister H, et al: Expression of p53 during mouse embryogenesis. Development 113:857-865, 1991

38. Schwartz D, Goldfinger N, Rotter V: Expression of p53 protein in spermatogenesis is confined to the tetraploid pachytene primary spermatocytes. Oncogene 8:1487-1494, 1993

39. Sheikh MS, Li SX, Chen JC, et al: Mechanisms of regulation of WAF1/Cip1 gene expression in human breast carcinoma: role of p53-dependent and independent signal transduction pathways. Oncogene 9:3407-3414, 1994

40. Ulbright TM, Orazi A, de Riese W, et al: The correlation of P53 protein expression with proliferative activity and occult metastases in clinical stage I non-seminomatous germ cell tumors of the testis. Mod Pathol 7:64-68, 1994

41. Valassiadou KE, Stefanaki K, Tzardi M, et al: Immunohistochemical expression of p53, bcl-2, mdm2 and waf1/p21 proteins in colorectal adenocarcinomas. Anticancer Res 17:2571-2576, 1997

42. Waldman T, Lengauer C, Kinzler KW, et al: Uncoupling of S phase and mitosis induced by anticancer agents in cells lacking p21. Nature 381:713-716, 1996

43. Wang J, Walsh K: Resistance to apoptosis conferred by Cdk inhibitors during myocyte differentiation. Science 273:359-361, 1996

44. Xiong Y, Hannon GJ, Zhang H, et al: p21 is a universal inhibitor of cyclin kinases. Nature 366:701-704, 1993

45. Zhang W, Grasso L, McClain CD, et al: p53-independent induction of WAF1/CIP1 in human leukemia cells is correlated with growth arrest accompanying monocyte/macrophage differentiation. Cancer Res 55:668-674, 1995

46. Zhang W, Kornblau SM, Kobayashi T, et al: High levels of constitutive WAF1/Cip1 protein are associated with chemoresistance in acute myelogenous leukemia. Clin Cancer Res 1:1051-1057, 1995

Manuscript received May 18, 1998.

Accepted in final form June 24, 1998.

This work was supported by the Kawano Masanori Memorial Foundation for Promotion of Pediatrics, Ministry of Education, Science, Sports, and Culture of Japan, and a Grant-in-Aid for Cancer research (9-12) from the Ministry of Health and Welfare of Japan.

Address reprint requests to: Ryo Nishikawa, M.D., Department of Neurosurgery, Saitama Medical School, 38 
Morohongo, Moroyama-machi, Iruma-gun Saitama-ken 350-0495, Japan. email: rnishika@saitama-med.ac.jp.

\section{Table of Contents Return ta N://OC(B)}

